Dr Matthew Tonts

Institute for Regional Development

The University of Western Australia

35 Stirling Highway, Crawley, 6009

Western Australia

Australia

Email: mtonts@segs.uwa.edu.au

Dr Fiona Haslam-McKenzie

Housing and Urban Research Institute of Western Australia

Curtin University of Technology

GPO Box U1987

Perth, 6845

Email: fiona.mckenzie@cbs.curtin.edu.au

Re-submitted to International Planning Studies, August 2005 


\title{
Neoliberalism and Changing Regional Policy in Australia
}

\begin{abstract}
This paper examines the role of neoliberalism in shaping Australian federal regional development policy over the past three decades. As in other parts of the world, since the 1980s Australian federal governments have tended to favour the role of market forces, as opposed to direct intervention in regional development. By the 1990s, however, the negative social and economic impacts of neoliberal approaches, together with a widespread electoral backlash, contributed to an adjustment in the direction of regional development policy. We argue that this transition is reflective of a wider shift in neoliberal politics, whereby limited government intervention and institution building are increasingly seen as appropriate policy responses. While in part this is linked to the shortcomings of previous policy approaches, it is also apparent that political opportunism is an important element of this shift.
\end{abstract}




\section{Neoliberalism and Changing Regional Policy in Australia}

\section{Introduction}

As in other areas of social and economic policy in Australia, regional development tends to be underpinned by neoliberal ideology. Since the early 1980s, governments of all political persuasions have eschewed interventionist strategies in favour of those based on market forces. Governments gradually dismantled the Keynesian regulatory architecture of the post war period, and pursued a political strategy based on deregulation of the economy, privatisation, a reduced commitment to social welfare, and a focus on international competitiveness (O’Connor et al., 2001; Beer et al., 2003a; Cocklin \& Dibden, 2004). For regional development, this resulted in a winding back of interventionist programmes aimed at ensuring socio-spatial equity, decentralised industrial development, and heavy investment in non-metropolitan infrastructure and services (Tonts, 1999). The emphasis was increasingly placed on local and regional competitiveness, economic efficiency, entrepreneurialism, and self-help development strategies (Herbert-Cheshire, 2000).

However, the mid 1990s represented another shift in federal regional development policy. While much of the early rhetoric about regional policy emphasised the role of markets in determining the location and distribution of economic activity, employment, and population, the 1990s saw increasing attention paid to the apparent shortcomings of market based solutions to regional problems (Alexander, 1994; Pritchard \& McManus, 2000). In a number of areas, neoliberal policy approaches had contributed to social disadvantage and economic upheaval (Alston, 2004). This eventually had significant electoral implications, with the rise of radical politics in a number of disaffected regions and electoral losses by a number of neoliberal reformist state governments. As a result, austere economistic approaches were tempered to take into account the range of social, economic and environmental problems facing regions (and, no doubt, to enhance electoral prospects). Indeed, limited government intervention and guidance gradually became embedded into the prevailing neoliberal policy framework. Significantly, Australia has not been the only place to experience this transformation in neoliberal policy making. Peck \& Tickell (2002) describe the 'mutation' of neoliberalism in North America and Europe as part of a response to growing concerns about the negative consequences of economic deregulation, labour reform and the degradation of welfare services (see also Wacquant, 1999). 
This paper examines the rise of neoliberalism in Australian federal regional development policy. In particular, it critically evaluates key federal policy measures implemented over the past 15 years or so. The paper also argues that there has been a discernable shift in neoliberal regional policy since the mid 1990s, reflecting a greater concern about the social and economic impact of reform on regions. However, rather than a radical departure from the prevailing neoliberal ideology, we suggest that this represents the type of transformation outlined by Peck and Tickell (2002), whereby new forms of government intervention and institution building have been embedded into contemporary neoliberal politics. The paper focuses on regional policy and planning as it applies to non-metropolitan and rural areas. This is consistent with current usage of the term regional in popular and political discourse in Australia (McManus \& Pritchard, 2001).

\section{Neoliberalism and Regional Development}

The 1970s marked a decisive shift in the economic trajectories and political strategies of developed nations. In response to global recession and the inability of traditional policies based on economic protectionism and the welfare state to resolve the economic crisis, many Western governments began to turn towards an alternative political strategy based on the principles of neoliberalism (Brenner \& Theodore, 2002). The proponents of neoliberal policy argued that, "market forces typically unleash growth, innovation and efficiency, whereas governmental regulations and expenditures typically impede growth, stifle entrepreneurship, and generate inefficiencies in both private and public sectors” (Head 1988, p. 466). In Australia, the widely held belief was that policy reforms based on the principles of neoliberalism would improve Australia's economic competitiveness and productivity, thereby restoring profits, economic growth and socio-economic well-being (O’Connor et al., 2001).

The neoliberal reforms of the 1980s and 1990s were generally driven by a radical shift away from postwar policies and regulatory frameworks based loosely around the principles of Keynsian economic management. In general terms, these reforms included: the liberalisation and deregulation of economies; the privatisation of state owned services and enterprises; the use of market principles (user pays etc.) in the public sector; and the reduction of welfare spending (Jessop, 2002). In terms of regional policy, neoliberalism has resulted in a retreat from proactive government involvement in economic development, infrastructure provision, and spatial planning (Hardy et al., 1995). Describing neoliberalism as a form of economic ‘jungle law', Peck \& Tickell (1994) have suggested that, in the United Kingdom, governments have abandoned regional policy to enable market forces to determine the spatial pattern of economic development (see also Massey 1995). A number of scholars have 
suggested that the outcome is often an uneven pattern of social and economic development, since capital tends to seek out those areas likely to generate maximum profit (Peck \& Tickell, 1995; Tonts \& Jones, 1997). So, where regional development policies have traditionally aimed to temper uneven development and promote spatial equity, the evidence indicates that free markets generate outcomes that are 'economically efficient' but geographically uneven (Alexander, 1994).

While neoliberals have been very successful in setting the agenda for economic reform in most advanced Western nations over the past two decades, they have not been without their critics (see Peck, 2001; Hamilton 2003; Pusey 2003). In his wide-ranging critique of neoliberal ideology, Head (1988, p. 466) argued:

In the bellicose form propounded by New Right ideologues, economic rationalism is a kind of cargo cult of the market, according to which abundance will materialise if only the enemies of progress (strong unions, high taxes, big government etc.) can be vanquished.

Much of the evidence would suggest that the abundance described by Head has not necessarily materialised under a neoliberal political regime. In many Australian rural areas, for example, neoliberal policies have resulted in the increasing economic vulnerability of family farming through further exposure to volatile market conditions (Gray \& Lawrence 2001). That these international markets are themselves distorted through farm subsidies and supports in other countries seems to make little difference to those arguing in favour of neoliberalism (Pritchard 2000). It has also been pointed out that 'economically rational' policies have contributed to the downsizing and closure of public services and infrastructure (Argent \& Rolley, 2000; Beer et al. 2003a). The rationale for this has usually been that the provision of services and infrastructure is not possible to justify in economic terms given population decline and the cost of cross subsidies (Taylor, 1991). The orthodox economic analysis often employed in contemporary policy making tends not to consider many of the resultant social costs associated with rural service withdrawal. Indeed, there is now considerable evidence to suggest that this prioritisation of economic efficiency over social needs has contributed to increasing levels of rural socio-economic inequality, deprivation, and marginalisation (Gray \& Lawrence, 2001; Lockie \& Bourke, 2001).

The 1990s, however, witnessed a transformation in the constitution of the international neoliberal project. As the increasingly perverse economic consequences and social externalities of economistic forms of neoliberalism become impossible to contest, a more socially interventionist approach began to emerge (Peck \& Tickell, 2002). In many respects, 
the so-called Third Way politics of the Blair, Clinton and (to a lesser extent) Keating governments epitomised this shift. For Jessop (2002), this involved rolling forward new forms of governance that include a degree of state intervention and institution building. As Wacquant (1999, p. 323) suggests, many of those who advocated less government intervention in the economy are now demanding: "more government to mask and contain the deleterious social consequences, in the lower regions of social space, of the deregulation of wage labour and the deterioration of social protection”.

While it is clear that economic concerns are still important, it is evident that new forms of intervention are emerging. Much of this intervention is focussed on issues such as crime, immigration, national security, welfare reform, urban regeneration, and regional regeneration. In terms of regional development, these interventionist strategies often involve new forms of governance, centred around partnerships with communities, business groups, and local government (Jones \& Ward, 2002). These partnerships are, however, based on public fiscal restraint, and aim to leverage private investment to support development. Thus, the intervention is not simply a re-creation of centralist Keynesian economic management, but a devolved form of governance that transfers responsibility, though not necessarily financial resources or political power, downwards and sideways (Jessop, 2002).

The focus of regional policy then is increasingly on new institutions and structures that encourage direct private sector investment in the pursuit of public policy objectives (Haughton et al., 2003). Governments in developed countries have established a range of institutions in pursuit of this objective, such as Area Consultative Committees in Australia, Regional Development Agencies in the United Kingdom, and Regional Economic Development Corporations in the United States. In addition, governments have invested considerable resources into various training and education strategies, designed to encourage localities and regions become increasingly self-reliant (Beer et al., 2003b). These programmes often focus on building community capacity, developing leadership, enhancing human and social capital, and encouraging greater volunteerism. The focus on these types of programmes is not surprising given neoliberals' concern with reducing the dependence of individuals and communities on state support. Together, these policy shifts have been particularly important in re-shaping the nature of Australian federal regional development policy. 


\section{Historical Context: The Whitlam Labor Government and DURD}

Australian federal approaches to regional development in the early 1970s represent a distinct contrast with the neoliberal strategies that were adopted in the early 1980s. During this period, the federal government saw itself having an important role to play in regional economic and social development. This was accompanied by a growing interest in issues associated with social equity. Indeed, poverty was 'rediscovered' as a political issue in the early 1970s and, in 1972, shortly before losing office, the McMahon Liberal-National Coalition government appointed the Henderson Commission of Inquiry into Poverty. A series of subsequent reports based on the inquiry identified growing levels of rural poverty as a serious problem (Henderson, 1975). While the Henderson inquiry provided empirical evidence of poverty in rural (and urban) Australia, 'quality of life' issues were already a major source of political debate.

In 1972, one of the Whitlam Labor government's responses to these debates was the establishment of the Department of Urban and Regional Development (DURD). The government argued that positive direct intervention would help stimulate social and economic development in rural regions (Lloyd \& Troy, 1981). In many respects, DURD was symbolic of the political and economic thinking of the time. Of particular significance was the view that governments could and should try to temper the spatial inequalities evident in economic and social development. DURD's major policy initiatives included: the division of the nation into formal planning regions; increased policy coordination between Commonwealth, State and local governments; direct financial assistance to local governments; a regional population distribution plan; and large scale spending on a number of selected growth centres.

However, DURD was not without its critics. One of the main problems was that DURD tended to focus more on urban issues than the challenges facing rural areas. Small country towns and remote areas were virtually ignored in favour of issues such as metropolitan infrastructure provision, public housing and urban social justice. Indeed, one of the only significant impacts of DURD on non-metropolitan Australia was the designation of growth centres, such as Albury-Wodonga on the NSW-Victorian border. Even this came under considerable criticism. Logan et al. (1975, p.104), for example, claimed that Australia simply did not have enough "population to support an extensive growth centre programme and (that) a modest, steady development of lower order regional centres should receive more support”. However, some of the most trenchant critics of DURD were the growing number of advocates of neoliberalism in the federal bureaucracy, conservative political parties, and elements of academia. Not only was DURD seen as a form of 'socialist' interventionism by some, its 
approaches to regional problems flew in the face of emerging neoliberal sentiments (Taylor, 2000). Opponents argued that the state had no role to play in regional development, and that the spatial distribution of economic activity, employment and population should be the outcome of market forces. Following the dismissal of Whitlam from office in 1975, DURD was almost immediate closed down by the newly elected Fraser Liberal-National Coalition government. The rationale was that it had been ineffective in dealing with urban and regional problems, was excessively costly, and that the federal government had not constitutional or ideological reason for being involved in regional development (see Lloyd \& Troy, 1981).

\section{Regional Development Post DURD}

Following the demise of the Whitlam government in 1975, and the closing of the DURD in 1976, policies concerned directly with regional development remained conspicuously absent from the federal agenda until the early 1990s. Throughout this period, regional development policy, insofar as it existed, tended to remain a responsibility of State governments. While there were repeated calls for a federal role in regional development, particularly following the election of the Hawke Labor government in 1983, these were ignored in favour of a noninterventionist approach that formed part of a broader neoliberal policy agenda. Indeed, Hawke's programme of reform mirrored those of other nations that had adopted the neoliberal project, with widespread deregulation of the economy through the reduction of tariffs, the liberalisation of banking and finance sectors, the privatisation of public assets, labour market reform, and a general retreat from policies of social and spatial redistribution (O'Connor et al., 2001). However, it is important to recognise that not all elements within the Labor Party supported the neoliberal agenda, with left wing factions continuing to argue for interventionist strategies, particularly in relation to regional development. While calls for greater state intervention were overlooked for nearly a decade, by the early 1990s, interest in regional development policies at a Commonwealth level had experienced something of a resurgence. One of the main reasons for this was the mounting evidence that the neoliberal policy reforms undertaken by the Hawke government, such as financial deregulation and trade liberalisation, had contributed to considerable social and economic disadvantage in some regions (Alexander, 1994; Stilwell, 1995). In addition, the absence of effective and redistributive regional development programs contributed to a concentration of investment in regions and localities that were conducive to capital accumulation (Beer et al., 2003a). Other regions that were, or had become, less conducive to capital accumulation tended to experience disinvestment and increasing peripheralisation (see, for example, Smailes, 1997; HaslamMcKenzie, 1999; Tonts, 2000; Cocklin \& Alston, 2003). While economic and social development has never been 'even' in Australia, this free market approach to regional 
development tended to intensify the existing spatial inequalities (Alexander, 1994). Indeed, considerable empirical evidence suggest that depressed regions tend to experience lower incomes, higher levels of welfare dependency, poor health, low levels of education, and other problems associated with social and economic underdevelopment (Cheers, 1998; AIHW, 1998; HREOC, 2000).

The second apparent reason for the re-emergence of a regional policy discourse at the federal level is largely political. The economic and social upheaval experienced in areas affected by policy reform had the potential to affect the Labor Party's chances of winning the 1993 federal election. Indeed, in many parts of the country, it was those areas most affected by policy reform that formed the traditional Labor constituency. Alexander (1994) argues that the rhetoric about regional policy simply smacked of ad hoc opportunism, rather than a genuine attempt to re-engage in a serious attempt to deal with problems of spatial inequity and disadvantage.

The majority of Commonwealth government inquiries into regional development issues in the early 1990s focused on the problem of socio-economic inequalities between regions. However, rather than a dramatic shift from a neoliberal policy agenda, these reformist policies were really about fine tuning the spatial pattern of capital accumulation (Stilwell, 1995). The first major report into regional development was produced by the Industry Commission in 1993. This report, Impediments to Regional Industry Adjustment, questions the need for any regional assistance at all, and advocated a continuation of economic liberalisation. The report targeted minimum wage levels, cross-subsidised transport infrastructure, public housing, and other public services as impediments to adjustment in regional areas. The Industry Commission's report also argued that welfare was a disincentive for people to accept full-time employment, and that lower social security payments would encourage beneficiaries to migrate to regions with better employment prospects.

The second major inquiry was conducted by the Taskforce on Regional Development (1993), which was established to investigate the prospects for a more even distribution of regional development and employment. The Taskforce report, Developing Australia: A Regional Perspective, emphasised the need to modernise transport and communications infrastructure, and improve education and employment opportunities in regional areas. The report also proposed the establishment of 66 Regional Economic Development Organisations across Australia to develop individual regional strategies, promote regional development, and improve policy co-ordination between Commonwealth, State and local governments. While the Taskforce report clearly identified problems and requirements on a region-by-region 
basis, many critics argued that it was both politically driven and little more than a series of 'wish-lists' from the regions.

Partly in response to these criticisms, the Commonwealth government commissioned a report into regional economic prosperity by management consultants McKinsey and Co. (1994). The McKinsey report, Lead Local Compete Global, emphasised the importance of regional and local leadership, of economic competitiveness, and of enhancing regional attraction by improving quality of life factors. These arguments were taken up further in a report by the Bureau of Industry Economics (1994), Regional Development: Patterns and Policy Implications, which advocates the importance of balanced regional economic and social development. The Bureau also recognised that, despite the plethora of reports emerging on regional development, there were still many unanswered questions concerning the trade-offs between equity and efficiency in determining regional policy.

In general the findings and recommendations of these reports reflect the transformation occurring in neoliberal policy during the 1990s. With the exception of the report of the Industry Commission, there was a general recognition that neoliberal policy reform had contributed to spatially inequitable economic and social development. Accordingly, there was an emerging recognition that there was a need for some sort of limited intervention in regional development. While the underlying discourse of the reports was still in favour of economic reform and the principles of neoliberalism, a new language began to emerge that emphasised capacity building, education, local leadership and guidance. Thus, what was being advocated was not a return to 'paternalistic' policies in which governments were the 'developers' of regions, but a model in which governments were seen as partners with regions and local communities.

In 1994, many of the findings of these reports were incorporated into the Commonwealth government's Working Nation program. This major initiative integrated employment, industry, and regional development policy. The regional development component of Working Nation was strongly influenced by the reports of McKinsey and Co. and the Taskforce on Regional Development. The focus of the regional development policy section of the program was on promoting regional leadership, infrastructure improvements, education and training programs, and the formation of the Regional Development Organisations (RDOs) to coordinate development between Commonwealth, State and local governments, as well as business and community groups. However, one of the immediate problems facing regional development under Working Nation was funding. Of the \$6.4 billion Australian dollars devoted to Working Nation, only \$263 million were directed at regional development. This 
represents only 4.1 per cent of the total budget. Thus, despite the rhetoric about regional development being an integral part of national economic development, in reality it remained a relatively marginal concern to the Commonwealth government.

For depressed rural areas, the policies were largely concerned with bottom-up development, and stated that, "regions should be encouraged to help themselves" (Commonwealth of Australia, 1994, p. 163). Although the programme did include funding for regional infrastructure (mainly roads and telecommunications) projects, these tended to be concentrated in rapidly growing areas, since Working Nation contained a caveat that projects should only proceed if they were economically viable in the long term (Sorensen, 1995). For many smaller rural communities, the most important elements of the policy were the focus on local and regional leadership and the formation of the RDOs to coordinate Commonwealth, State and local programs.

\section{Regional Development Organisations}

The Commonwealth government's RDOs were part of an attempt to establish planning and development units that would provide a degree of political and spatial coherence at a regional level. However, in reality this did not occur. The formation and operation of the RDOs was not supported by specific legislation, and it was largely up to State governments and individual regions to establishment these bodies, albeit with some limited financial support from the Commonwealth. There was no single model for an RDO, and the only requirement was that the membership of the RDOs management committee be broadly based. Typically, this would include representatives from local government, industry, educational institutions, environmental organisations, and unions. Since the formation of RDOs was voluntary, the level of representation was to be decided by the various interest groups within a region.

Despite some community expectations of generous funding allocation for RDOs, relatively meagre funds were made available (combined, \$150 million over four years). The Commonwealth's stated intention to establish 40 RDOs meant that the average total funding for each RDO, if evenly distributed, would be about $\$ 4$ million. There was a general view that the limited funds available were not sufficient incentive to make the effort or the compromises required to form RDOs (Forth, 1996). However, the overall focus and role of the RDOs was not to distribute funding to regions. It was the coordination of policy and, perhaps more importantly, provide a framework in which regions could pursue their own social and economic development objectives. Indeed, the RDOs were largely about promoting development from the grass roots (Maude, 2003). Most of these organisations 
focussed on education, economic planning, business recruitment strategies, tourism development, and establishing public-private partnerships in pursuit of economic development. In many respects, this reflects the shifting approach to regional development occurring elsewhere in the world, where by the mid 1990s the focus was no longer simply on hard line economic approaches, but those that emphasised community involvement, local level responses, and public-private partnerships (Brenner \& Theodore, 2002). Thus, Working Nation and the RDOs represented a relatively significant change in policy rhetoric. There was at least a partial recognition that free-market forces might not always deliver socially equitable or economically desirable outcomes. Furthermore, the Commonwealth saw itself as playing at least some role in spatial planning and regional development. However, it is also clear that the government remained committed to the principles of neoliberalism. Indeed, there was no suggestion that the Commonwealth was about to invest large sums of money in policies aimed at promoting economic and social development. The focus remained on the libertarian ideals of self-help, entrepreneurialism, and the promotion of market forces.

\section{Regional Development Under Howard: Leading the Way?}

In 1996, a change of government resulted in yet another shift in regional policy. The 1996 federal election campaign saw Labor adopt an increasingly interventionist rhetoric in relation to regional policy. The government promised that, if re-elected, funding to regional programmes would be increased, new regional infrastructure projects would be supported (particularly for the construction of rail and road services), that rural services would be maintained, and that significant sums would be invested in environmental rehabilitation. By contrast, the John Howard led Coalition tended to remain largely silent on the issue of regional development, focussing on a range of popular issues, such as unemployment, home loan interest rates, and the cost of living.

Upon winning the election, Howard soon announced a series of major policy reforms aimed at further liberalising the economy and downsizing the public service. This represented a return to the more 'hard-line' neoliberal agenda that had characterised Australian politics in the 1980s. One of the first major announcements of the new Howard government was an inquiry by the National Committee for Audit into the public service. In its analysis of Commonwealth regional development, the Committee suggested that many regional programmes were inefficient and ineffective. They also claimed that, "current arrangements for regional development and urban management overlap with State and local government responsibilities” (National Committee of Audit, 1996, p. 78). This finding provided the trigger for the Coalition to terminate all regional programmes. In many respects, there was a 
sense of déjà vu with the Coalition adopting a similar line to the one they had in 1976 when they dismantled most of Whitlam's regional initiatives.

Under the Howard government, the Department of Transport and Regional Development was renamed the Department of Transport and Regional Services. While initially this may appear simply a question of semantics, it actually represents a more significant underlying ideological shift in the nature and operations of the Department. The de-emphasis of 'development' reflected the belief of the government that, where possible, the state should not intervene in the economies of regions, and that market forces were the most appropriate means of determining economic and social outcomes. Instead, by emphasising services, the government could simply focus on basic public amenities, particularly transport and telecommunications infrastructure. The extent of the change was also reflected in the staffing arrangements in the Department. Prior to the election of the Coalition more than 150 staff were dedicated to regional development. Following the restructure, this was reduced to a group of eight people working in a 'Regional Affairs Unit'.

The lowly position of regional development within the Commonwealth government was further emphasised by the policy document Regional Australia: Leading the Way, which was released at the time of the 1996 Federal Budget. This statement made no contribution to the formulation of a dedicated Coalition regional development policy. It aimed "to improve the standard of living of all Australians - no matter where they live” (Sharp, 1996, p.1), through micro-economic reform and tried to convince the electorate that this was the only way to achieve a positive economic and social future for regional areas. The statement was used to explain how economic reform, particularly deregulation, privatisation and user pays initiatives, would benefit regions. Underlying this document was a clear commitment to a neoliberal policy platform that eschewed state intervention in favour of market forces. It also conveyed a naïve understanding of the role of geographic space in regional development (Tonts \& Jones, 1997). Indeed, the government failed to recognise the enormous spatial variation in the nature of economic and social development and the significance of developing policies that are sensitive to these complex economic and social geographies.

The 1998 statement Regional Australia: Our Commitment was little different to the earlier document. Again, it stated that "the Commonwealth's primary responsibility [is] for the national economy, in both macro-economic and micro-economic management and reform, which in turn depends significantly on the strength of regional Australia” (Vaile \& Somlyay, 1998, p. 1). The overview does, however, acknowledge that conditions in regional Australia vary and that environmental problems have the potential to undermine the capacity of some 
regions to sustain or expand their economic base, although the policies do not reflect differences in regional needs.

\section{The One Nation Phenomenon and the Regional Electoral Backlash}

While regional policy tended to be shaped by the principles of neoliberalism, the Howard government failed to anticipate the extent of disenchantment affecting people in rural areas. As McManus \& Pritchard (2001) have pointed out, more than a decade of service withdrawal, economic reform and growing levels of disadvantage had begun to take their toll in Australia's non-metropolitan regions (see also Davis \& Stimson, 1998; Collits, 1998; Lockie \& Bourke, 2001; Gray \& Lawrence, 2001). To some extent this was reflected in the rise of Pauline Hanson's radical One Nation party, which advocated greater economic support for rural areas, a return to protectionism, and an improvement in rural service provision. One Nation emerged following the election of the right wing Pauline Hanson at the 1996 federal election. Hanson's agenda was largely opportunistic and included advocating greater support for traditional heartland industrial and agricultural areas that had been negatively affected by economic restructuring and neoliberal policies. Hanson was a vocal critic of policies that resulted in reduced support for those sectors and regions that had traditionally been important to Australia’s economic prosperity (see McManus and Pritchard, 2001).

The success of One Nation in the 1998 Queensland State election, where it won 11 out of 89 seats (and 22.7 per cent of the primary vote), saw regional development return to the Commonwealth political agenda as One Nation threatened to win the votes of disaffected Australians and remove the Howard government from office. There has been vigorous debate about why Hanson and the One Nation Party were able to capture a significant proportion of the primary vote in Queensland and subsequently to rally large crowds throughout Australia (Badcock, 1998; Davis \& Stimson, 1998). It is generally accepted that Hanson’s platform of championing the Australian battler, those most hurt or threatened by the market driven economic policies, the insecurities of globalisation and increasing competition, while at the same time denigrating government expenditure on foreign aid, immigration and Aboriginal programmes appealed to many disillusioned voters. Rural people perceived that they were losing control of their lifestyles and had been ignored by their elected representatives from the major parties (Davis \& Stimson, 1998). Somewhat tellingly, it was the rural based National Party, the junior member of the Coalition government, that was most affected by the Hanson phenomenon. Indeed, it is somewhat ironic that it was a National Party MP (John Sharp) who, in 1996, formally abandoned the former Labor government's regional development policies. Ideologically, it would seem that Sharp had misread the electorate. Displaying a 
degree of political amnesia, a short time later in a newspaper interview about the rise of the One Nation Party Sharp stated that rural people:

... want to be heard and respected and want to be included in Australia's future. Not so long ago, they were considered to be the very heartland of Australia. Today they feel ignored. They live in communities that are dying. They work in industries that have collapsed. They are desperate and looking for something different and are vulnerable to political manipulation (Sharp, 1998, p.12).

As the junior partner in the Coalition government, the National Party was unable to counter the federal Liberal Party's ideological drive for non-interventionist policies in regional and other matters. Notwithstanding this, the leader of the National Party claimed that:

One of the National Party's most vital roles is to ensure that government policies - designed of course with the best intentions to benefit the nation overall - do not inadvertently damage country people (Anderson, 1999, p.13).

The potential impact of voter disenchantment at the federal level become even more obvious in 1999 when the Kennett Coalition State Government in Victoria lost office. Voters throughout Victoria felt that they had been hard done by as a result of government economic reform and felt that their government had little regard for their welfare or livelihoods. In the lead up to the election, health, education and infrastructure were the overriding issues (Barlow, 2000). This was particularly evident in four strictly rural electorates: Benalla and Seymour, both in Central Victoria; Narracan in Gippsland, an area dominated by dairying; and Gisborne, an electorate north west of Melbourne in Victoria. What came as a shock to the Victoria State Coalition was that significant numbers of traditional, conservative Liberal voters did the 'unthinkable' and voted Labor (Barlow, 2000).

In the Western Australian State election in February 2001, the Coalition lost government to the Labor party. While the One Nation Party did not win a large number of seats, they, together with the Greens, hold the balance of power in the Upper House of the Western Australia State Parliament. For the rural-oriented National Party, the election was a disaster and reinforced how 'out of touch' the electorate perceived the party to be. It was clear that, just as happened in the Victorian State election, previously committed National Party supporters voted for Labor. The National Party lost two seats and was precariously close (one seat) to losing major party funding from the State government. It was clear that the Western Australian National Party had not absorbed the warnings at a national level and that the rural and regional electorates were disappointed and disillusioned with the National Party and its ‘tired' neoliberal agenda in Western Australia. 
As a results of the inroads made by the One Nation Party in Queensland, and the landslide electoral results against the Coalition in Victoria in 1999 and Western Australia in 2001, the major political parties were keen to reinvent themselves and rewrite government policies to attract back disenfranchised rural and regional voters (Davis and Stimson, 1998). As stated by Paul Collits, policy manager of the New South Wales Department of State and Regional Development:

there has been a marked move by all the major parties away from their previous unfettered embrace of micro-economic reform and globalisation. One Nation Party succeeded in moving the political goalposts where others, (the National Party, the Regional Australia Now movement, the New South Wales Country Summit Taskforce, the New South Wales Country Mayors' Association and various other regional advocates who adhere to notions of 'balanced development') have failed (Collits, 1998, p. 23).

For Howard, appealing to disaffected regional voters was essential for political survival. Thus, it is not surprising that in the late 1990s, just when voters were turning against the Coalition government that regional policy reappeared on the political agenda. The approach adopted by Howard was not dissimilar to that advocated in the earlier Working Nation policy. In a major policy statement, Regional Australia: Meeting the Challenge, the Deputy Prime Minister, John Anderson, emphasised the importance of communities taking responsibility for their own futures (Anderson \& MacDonald 1999). He stressed the role of local leadership, the need for people to work together, and the importance of entrepreneurialism. Much of this continues to reflect an underlying neoliberal ideology. Not only does it de-emphasise the role of government, but it reinforces notions such as personal and collective responsibility and, by promoting entrepreneurialism, tends to stress the importance of competition and the market. Beer (2000) also suggests that the regional package is as important for the issues about which it is silent, as it is for those that it discusses:

What is absent is a commitment by the federal government to funding general regional development programs: there is no regional infrastructure funding program, there is no financial support for existing regional development bodies and there is no funding for programs or projects submitted as priorities by the regions (Beer, 2000, p. 179).

Indeed, in many respects the regional strategy smacked of tokenism and political opportunism. This was further emphasised by a one-off Regional Australia Summit in October 1999 that had as its core aim drawing "together business and community representatives from across the nation to address the challenges facing rural and regional Australia” (Anderson \& McDonald, 1999, p. 2). While this gave the impression of being an 
attempt by the government to understand the issues facing non-metropolitan regions, it did little to change government policy. Indeed, the Summit was as much about a platform for promoting existing government ideology and policy as a genuine attempt to engage with people living in regional Australia.

There were a number of other regional initiatives that were perhaps more constructive than the Regional Summit. After vigorous lobbying from various groups, particularly the National Forum on Women in Agriculture and Resource Management (Alston, 1995), the 1999 Budget included the establishment formal Regional Impact Statements that required various Commonwealth government departments to address the potential regional impacts of all Cabinet submissions. Another initiative was a Memorandum Of Understanding on regional development between key portfolios, such as the Departments of Transport and Regional Services; Agriculture, Forestry and Fisheries Australia; and the Department of Education Training and Youth Affairs. The Howard Coalition Government also placed great emphasis on the services it provides to the regions. It announced that part of the proceeds of the sale of the second tranche of the national telecommunications provider Telstra would be used to provide 500 Rural Transaction Centres to replace banking facilities that had been withdrawn from country towns.

By the 2001 and 2004 federal elections, regional issues had begun to take a back seat to global issues. Howard's tough stance on illegal immigrants, together with global uncertainty in the wake of the terrorist attacks in the USA in September 2001 saw the Coalition reelected. Furthermore, Pauline Hanson’s One Nation Party has virtually collapsed following a number of internal disputes and rifts. Nevertheless, the Coalition appears to have recognised that neoliberal policies have the potential to cause considerable electoral damage, particularly in vulnerable regions. As a consequence, the Commonwealth government has continued to support a range of regional development programmes. The shift in regional policies was not dissimilar to that initiated by the earlier Keating Labor government under Working Nation, which advocated limited government intervention. In both cases, it was the potential electoral impact of neoliberal policies that contributed to the shift. Thus, rather than a fundamental ideological shift, the transformation was as much about political opportunism than a dramatic rethink of the virtues of neoliberal policy approaches. However, there are also some broad similarities with the transformation of neoliberalism in other parts of the world, where the perverse impacts of this policy framework have seen limited state intervention emerge through public-private partnerships, capacity building initiates and the formation of regional planning and development bodies (Brenner \& Theodore, 2002). 


\section{Area Consultative Committees}

In Australia, one of the strategies adopted by the federal government was to support a network of 56 Area Consultative Committees. Initially the purpose of these organisations was to advise on, and generate support for, the Commonwealth Government's labour force initiatives, making employment and training programmes more relevant to local needs. Increasingly however, the ACCs position themselves as key regional stakeholders, seeking to build networks and partnerships and developing local solutions to local problems, "providing a vital conduit to government on local, social and economic conditions, promoting and disseminating information on Government priorities and programmes to achieve regional economic growth” (www.acc.gov.au).

It is now expected that these private sector-led partnerships provide advice to the community and government, as well as networking and lobbying with their communities to assist in the development of job opportunities for regional communities, broader regional economic development strategies and partnerships (Beer, 2000). More recently, they have been used by government as a key facilitator of change and in the development of regional planning strategies. These organisations now have a larger budget than the regional development programmes under Working Nation, which were dismantled in 1996 by the Coalition on the grounds that the federal government had no constitutional role in regional development (Maude, 2003). The growing role of the ACCs is, in many respects, a reflection of the subtle shifts in regional policy in response to the negative impacts of neoliberalism and is not dissimilar to the types of regional organisations established in parts of Europe and North America in the face of similar problems (Haughton et al., 2003).

The activities and organisation of the Western Australian Wheatbelt Area Consultative Committee provides a useful example of the activities of these regional bodies. The Western Australian Wheatbelt Area Consultative Committee jurisdiction covers 44 local government authorities over an area roughly the size of Spain (Figure 1). Approximately 72,000 people live in the Wheatbelt, many in small towns, few of which have more than 5,000 residents. As its name suggests, the dominant industry in the Wheatbelt is broadacre agriculture and, since the early 1980s, farmers have experienced a cost-price squeeze where returns for produce have diminished while the costs of inputs have increased, causing real income to drop (Gray \& Lawrence, 2001). Farm amalgamations have occurred in the region as farmers have sought to achieve economies of scale, thereby maintaining similar rates of return. As a consequence, there has been an ongoing movement of people away from the region , usually to coastal areas or the Perth metropolitan area (see Tonts, 2005). At the same time, the role of government 
has continued to move from being the supplier of social services and infrastructure to one guided by goals of economic efficiency (Sorensen, 2002).

\section{[INSERT FIGURE ONE ABOUT HERE]}

The Wheatbelt ACC dedicates a great deal of its key economic development and funding initiatives to developing the capacity of those who still live in the region and nurturing strategies to provide economic and social support for rural industries and communities. This includes promoting regional business opportunities such as the Regional Branding and Promotion project. The participants in the Regional Branding group are focussed on new ways of value-adding and marketing commodities produced in the Wheatbelt. It is an active collaboration between business and government, and aims to achieve competitive advantage in a global environment. Their aim is to develop new markets in the capital city, Perth and beyond. Participants have been farmers, town businesses and indigenous groups. The key role of the ACC has been to provide business training, guidance, and access to networks. It also aims to stimulate co-operation, mutual understanding of the different communities' and industries' challenges and advantages as well as the formation of a forceful lobbying group. The Regional Branding initiative has succeeded in overcoming elements of community and small town parochialism, replacing it with a commitment to collaboration, regional pride and determination for success. However, it also fits squarely with neoliberal principles of selfhelp and entrepreneurialism, albeit with a degree of government intervention and assistance.

Another example of crucial Wheatbelt Area Consultative Committee involvement in the region has been the development of the Rural Transaction Centre programme. Due to the pressures associated with deregulation and rationalisation, postal, banking, telecommunications and government agricultural advisory services have been centralised, often in the same larger urban regional centre. These closures led to changes in local spending levels, savings and borrowing patterns, negatively impacting on both local businesses and the community (Argent \& Rolley, 2000). Allied to this change, the loss of confidence in the future of the community and the unwillingness of businesses to invest in these areas had a major impact. This has often been to the detriment of the smaller towns such as those that predominate in the Wheatbelt region, and which have worked hard to scrape back some of their lost resources, vibrancy and popularity. 
In response to the closure of banks and business support services throughout regional areas, Rural Transaction Centres have been developed as part of a government led response to the problem of service withdrawal. Rural Transaction Centres provide a 'one-stop' business centre that incorporates a number of services depending on the needs of the local area. Usually, Rural Transaction Centres provide space and facilities for a range of government and non-government services. These might include a banking facility for visiting banks, a postal service, a technology centre or telecentre, and meeting rooms. In the Central Wheatbelt, the Rural Transaction Centre at Corrigin also houses a toy library, offices for casual and permanent rent, a small conference/meeting room and a small mini-cinema (Wheatbelt Area Consultative Area Committee, 2004). At Westonia, an even more remote community, the Rural Transaction Centre provides local library facilities, a telecentre, meeting rooms, space for the Royal Flying Doctor consultations, an office for volunteer environment workers, and the technology for the printing of a community newsletter. The services and infrastructure located at the Rural Transaction Centres are important for local commerce but are equally, if not more valued for their contribution to sustaining the sense of community. The establishment of Rural Transaction Centres is normally undertaken as a partnership between the ACC and local business and community groups.

In essence, the role of the ACCs has been to soften the impacts of structural adjustment in Australia's regions through a series of lightly funded programmes that are designed to foster greater self-reliance and entrepreneurialism. While these organisations do represent a form of state intervention, in no way can they be regarded as a return to the top-down approaches of the 1970s. Indeed, the approach parallels the notion of a reformed neoliberalism in which limited intervention is seen as appropriate (Jessop, 2002), so long as it does not unduly interfere with the mechanics of the market and, in the longer run, leads to reduced dependence on the state.

\section{Conclusion}

In its present form, regional policy in Australia still conforms strongly to the principles of neoliberalism. None of the current programmes advocate a return to significant intervention by the state into regional development. Furthermore, those policies that are in place tend to favour localities and regions taking responsibility for their own economic and social development and planning. This is reflected in programmes aimed at, inter alia, fostering local leadership, promoting locally initiated revitalisation strategies, and community participation in local decision-making. However, the fact that such government programmes do exist is illustrative of the changes evident in neoliberal policymaking. During much of the 
1980s, and in the early years of the Coalition government in the mid 1990s, almost all forms of government intervention in regional development were eschewed in favour of marketoriented approaches. The failure of this approach, and the political impact, contributed to considerable adaptation and transformation of the neoliberal project, to one in which limited government intervention was seen as having a distinct role (see also Peck \& Tickell, 2002). In effect, there has been a shift from the austere economic rationalism to a somewhat softer form of neoliberalism that recognises some of the limitations of the free market. This is consistent with trends in regional development in other parts of the world, where governments have begun to recognise that they a role to play in ensuring that the market does not unduly disadvantage certain regions or groups of people within regions (Brenner \& Theodore, 2002). However, it is also clear that the rhetoric of regional policy has been at its strongest in Australia (and elsewhere) at those moments when governments are facing electoral difficulties in the very regions affected by restructuring and neoliberal policy reforms. The danger with this approach is that it can undermine the prospects of coherent, long-term regional strategies. This has certainly been the case in Australia, where the fortunes of regional policy have often waxed and waned according to political crises, rather than the real needs of regions and their inhabitants. 


\section{References}

AIHW [Australian Institute of Health and Welfare](1998) Health in Rural and Remote Australia (Canberra: Commonwealth of Australia).

Alexander, I. (1994) DURD revisited? Federal policy initiatives for urban and regional planning 1991-94, Urban Policy and Research, 12(1), pp. 6-26.

Alston, M. (1995) Women on the Land: The Hidden Heart of Rural Australia (Sydney: University of New South Wales Press).

Alston, M. (2004) Social exclusion in rural Australia, in: C. Cocklin \& J. Dibden (Eds) Sustainability and Change in Rural Australia, pp. 157-170. (Sydney: University of New South Wales Press).

Anderson, J. (1999) One Nation or Two? Securing a Future for Rural and Regional Australia, Canberra, National Press Club.

Anderson, J. \& MacDonald, I. (1999) Regional Australia: Meeting the Challenges (Canberra: Commonwealth of Australia).

Argent, N. \& Rolley, F. (2000) Lopping the branches: bank branch closures and rural Australian communities, in: W. Pritchard \& P. McManus (Eds) Land of Discontent: The Dynamics of Change in Rural and Regional Australia, pp. 140-168 (Sydney: University of New South Wales Press).

Badcock, B. (1998) Forgotten places, excluded citizens and the rise of One Nation, Urban Policy and Research, 16, pp. 241-246.

Barlow, G. (2000) Backlash, Weekly Times, 19 April, pp. 1.

Beer, A. (2000) Regional policy and development in Australia: Running out of solutions?, in: W. Pritchard \& P. McManus (Eds) Land of Discontent: The Dynamics of Change in Rural and Regional Australia, pp. 169-194 (Sydney: University of New South Wales Press).

Beer, A., Maude, A. \& Pritchard, W. (2003a) Developing Australia's Regions: Theory and Practice (Sydney: University of New South Wales Press).

Beer, A., Haughton, G. \& Maude, A. (2003b) Local and regional economic development organisations in international comparison, in: A. Beer, G. Haughton, \& A. Maude (Eds) Developing Locally: An International Comparison of Local and Regional Economic Development, pp. 37-60 (Bristol: The Policy Press).

Brenner, N. \& Theodore, N. (2002) Cities and the geographies of 'actually existing neoliberalism', in: N. Brenner \& N. Theodore (Eds) Spaces of Neoliberalism: Urban Restructuring in North America and Western Europe, pp. 2-32 (Oxford: Blackwell Publishing).

Bureau of Industry Economics (1994) Regional Development: Patterns and Policy Implications (Canberra: Australian Government Publishing Service).

Cheers, B. (1998) Welfare Bushed: Social Care in Rural Australia (Aldershot: Ashgate).

Cocklin, C. \& Alston, M. (Eds)(2003) Community Sustainability in Rural Australia. (Wagga Wagga: Centre for Rural Social Research, Charles Sturt University).

Cocklin, C. \& Dibden, J. (Eds)(2004) Sustainability and Change in Rural Australia (Sydney: University of New South Wales Press).

Collits, P. (1998) Hilmer, Hanson and Regional Development: The Impact of Competition Policy on Regional Australia and the Political Response. Paper presented at the Australia and New Zealand Regional Sciences Association International Conference, Tununda, South Australia.

Commonwealth of Australia (1994) Working Nation: Policies and Programs (Canberra: Australian Government Publishing Service).

Davis, R. and Stimson, R. (1999) Disillusionment and disenchantment at the fringe: explaining the geography of the One Nation party at the Queensland election, People and Place, 6(3), pp. 69-82.

Forth, G. (1996) Redrawing the map of Australia: the Commonwealth's regional development program, Australasian Journal of Regional Studies, 2(1), pp. 75-86.

Gray, I. \& Lawrence, G. (2001) A Future for Regional Australia: Escaping Global Misfortune (Cambridge: Cambridge University Press). 
Hamilton, C. (2003) Growth Fetish (Sydney: Allen and Unwin).

Hardy, S., Hart, M., Albrects, L. and Katos, A. (Eds)(1995) An Enlarged Europe: Regions in Competition (London: Jessica Kingsley).

Haslam-McKenzie, F. (1999) The Impact of Declining Infrastructure in Rural Western Australia (Canberra: Rural Industries Research and Development Corporation).

Haughton, G., Beer, A. \& Maude, A. (2003) Understanding international divergence and convergence in local and regional economic development, in: A. Beer, G. Haughton, \& A. Maude (Eds) Developing Locally: An International Comparison of Local and Regional Economic Development, pp. 15-36 (Bristol: The Policy Press).

Head, B. (1988) The Labor government and economic rationalism, Australian Quarterly 60, pp. 466-477.

Henderson, R. (1975) Poverty in Australia, Volume 1-First Main Report (Canberra: Australian Government Publishing Service).

Herbert-Cheshire, L. (2000) Contemporary strategies for rural community development in Australia: a governmentality perspective, Journal of Rural Studies, 16, 203-215.

HREOC [Human Rights and Equal Opportunities Commission] (2000) Education Access: National Inquiry into Rural and Remote Education (Sydney: Human Rights and Equal Opportunities Commission).

Industry Commission (1993) Impediments to Regional Industry Adjustment. (Canberra: Industry Commission).

Jessop, B. (2002) Liberalism, neoliberalism and urban governance: a state-theoretical perspective, Antipode, 34, pp. 452-472.

Jones, M. \& Ward, K. (2002) Excavating the logic of British urban policy: neoliberalism as the 'crisis of crisis-management', in: N. Brenner \& N. Theodore (Eds) Spaces of Neoliberalism: Urban Restructuring in North America and Western Europe, pp. 126-147 (Oxford: Blackwell Publishing).

Lloyd, C. \& Troy, P. (1981) Innovation and Reaction: The Life and Death of the Federal Department of Urban and Regional Development (Sydney: George Allen and Unwin).

Lockie, S. \& Bourke, L. (Eds)(2001) Rurality Bites. The Social and Environmental Transformation of Rural Australia (Sydney: Polity Press).

Logan, M., Mather, C., McKay, J. \& Humphreys, J. (1975) Urban and Regional Australia: Analysis and Policy Issues (Melbourne: Sorrett).

Massey, D. (1995) Spatial Divisions of Labour: Social Structures and the Geography of Production (Second Edition)(Basingstoke: Macmillan).

Maude, A. (2003) Local and regional economic development organisations in Australia, in: A. Beer, G. Haughton, \& A. Maude (Eds) Developing Locally: An International Comparison of Local and Regional Economic Development, pp. 109-136 (Bristol: The Policy Press).

McKinsey \& Company (1994) Lead Local, Compete Global: Unlocking the Growth Potential of Australia's Regions (Report to the Office of Regional Development, Department of Housing and Regional Development)(Sydney: McKinsey and Co).

McManus, P. \& Pritchard, W. (2001) Geography and the emergence of rural and regional Australia, Australian Geographer, 31, pp. 383-391.

National Committee of Audit (1996) Report to the Commonwealth Government (Canberra: Australian Government Publishing Service.

O’Connor, K., Stimson, R. \& Daly, M. (2001) Australia's Changing Economic Geography (Melbourne: Oxford University Press).

Peck, J. (2001) Workfare States (Guilford: New York).

Peck, J. \& Tickell, A. (1994) Jungle law breaks out. neoliberalism and the global-local disorder, Area, 26, pp. 317-326.

Peck, J. \& Tickell, A. (1995) The social regulation of uneven development: regulatory deficit, England's south east, and the collapse of Thatcherism, Environment and Planning A, 27, pp. 15-40.

Peck, J. \& Tickell, A. (2002) Neoliberalising space, Antipode, 34, pp. 380-404. 
Pritchard, W. (2000) Negotiating the two-edged sword of agricultural trade liberalisation, in: W. Pritchard \& P. McManus (Eds) Land of Discontent: The Dynamics of Change in Rural and Regional Australia, pp. 90-104 (Sydney: University of New South Wales Press).

Pritchard, W. \& McManus, P. (Eds)(2000) Land of Discontent: The Dynamics of Change in Rural and Regional Australia (Sydney: University of New South Wales Press).

Pusey, M. (2003) The Experience of Middle Australia: The Dark Side of Economic Reform (Cambridge: Cambridge University Press).

Sharp, J. (1996) Regional Development (Media Statement )(Canberra: Minister for Transport and Regional Development).

Sharp, J. (1998) Sydney Morning Herald, 19 June, pp. 21.

Stilwell, F. (1995) Regional policy initiatives: a political economy perspective, Australian Journal of Regional Studies, 9, pp. 49-63.

Smailes, P. (1997) Socio-economic change and rural morale in South Australia, 1982-1993, Journal of Rural Studies, 13, pp. 19-42.

Sorensen, A. (1995) Working Nation: a new approach to regional development? Australian Journal of Regional Studies, 8, pp. 39-48.

Sorensen, A. (2002) Regional economic governance, in: S. Bell (Ed) Economic Governance and Institutional Dynamic (Melbourne: Oxford University Press).

Taskforce on Regional Development (1993) Developing Australia: A Regional Perspective (Canberra: Australian Government Publishing Service).

Taylor, M. (1991) Economic restructuring and regional change in Australia, Australian Geographical Studies, 29, pp. 255-267.

Taylor, M. (2000) The dynamics of Australian regional policy: lessons for Europe? Federal and Regional Studies, 10, pp. 107-125.

Tonts, M. \& Jones, R. (1997) From state paternalism to neoliberalism in Australian rural policy, Space and Polity, 1, pp. 171-190.

Tonts, M. (1999) Some recent trends in Australian regional economic development policy, Regional Studies, 33, pp. 581-586.

Tonts, M. (2000) The restructuring of Australia's rural communities, in: W. Pritchard \& P. McManus (Eds) Land of Discontent: The Dynamics of Change in Rural and Regional Australia, pp. 52-72 (Sydney: University of New South Wales Press).

Tonts, M. (2005) Internal migration and Australia's inland agricultural regions, Dialogue, 13, 27-37.

Vaile, M., \& Somlyay, A. (1998).Regional Australia: Our Commitment (Canberra: Minsters for Transport and Regional Development and Regional Development, Territories and Local Government)

Wacquant, L. (1999) How penal common sense comes to Europeans: notes on the transatlantic diffusion of the neoliberal doxa, European Societies, 1, pp. 319-352.

Wheatbelt Area Consultative Area Committee (2004) Wheatbelt Area Consultative Area Committee [Online]. Available: http://www.wheatbeltacc.com.au. 


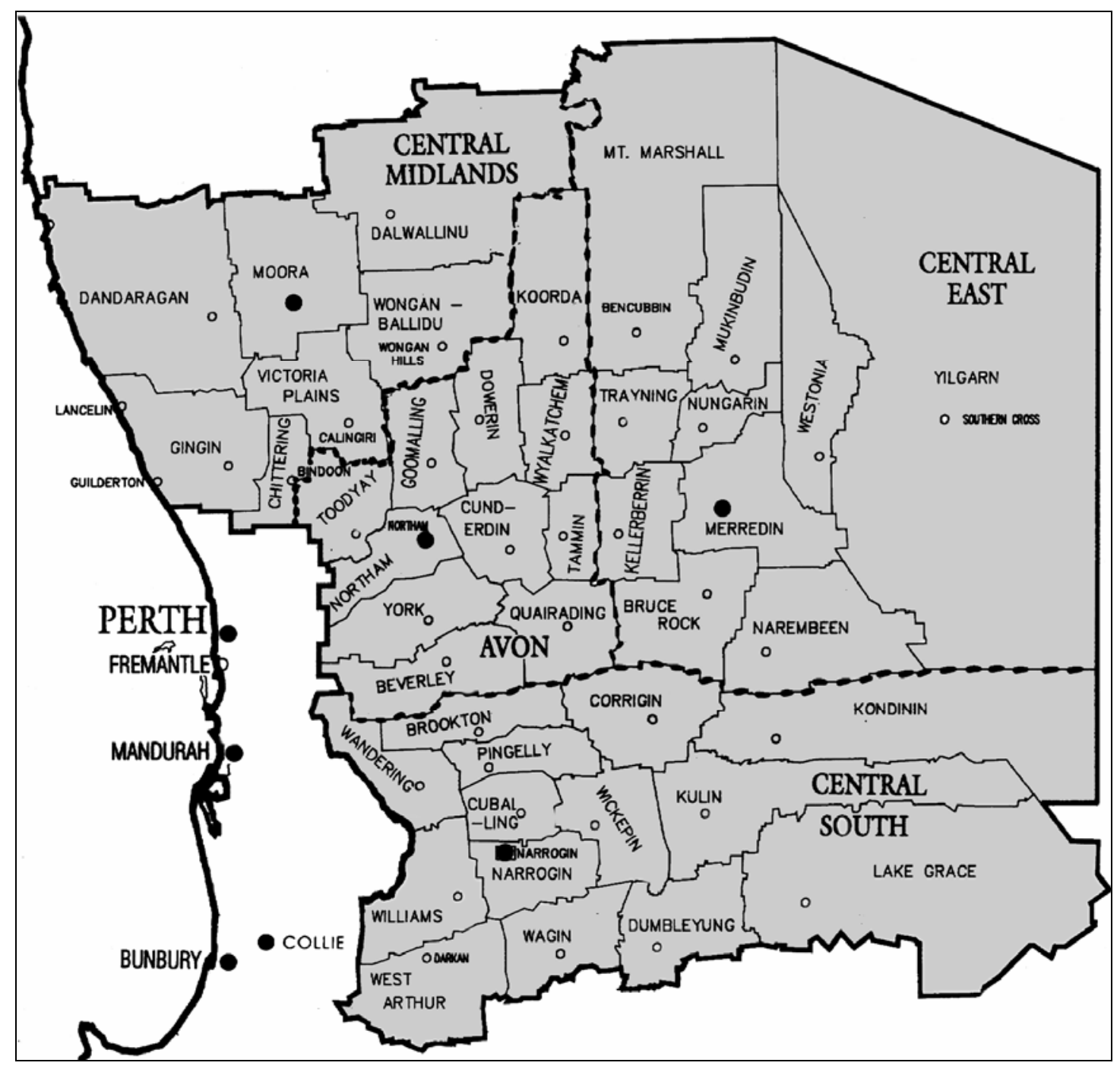

Figure 1 The Wheatbelt Area Consultative Committee Jurisdiction 